\title{
ANALYSIS OF INCIDENCE OF THROMBOEMBOLIC COMPLICATIONS IN PATIENTS WITH CHRONIC LYMPHOPROLIFERATIVE DISEASES
}

\author{
Srđan Nikolovski ${ }^{1}$, Biljana Mihaljević \\ ${ }^{1}$ Medicinski fakultet, Univerzitet u Beogradu, Srbija \\ ${ }^{2}$ Mentor: Klinika za hematologiju Kliničkog centra Srbije \\ Contact e-mail: srdjan.nikolovski@yahoo.com
}

Sažetak

Uvod: Kod pacijenata sa solidnim tumorima uočen je povećan rizik za nastanak tromboembolija, međutim za pacijente sa malignim limfomima postoji malo podataka.

Cilj: Cilj ovog rada bio je odrediti incidencu TE kod pacijenata sa non-Hodžkin limfomima (NHL), Hodžkin limfomima (HL) i hroničnom limfocitnom leukemijom (HLL) koji su zbrinuti u našoj instituciji.

Materijal i metode: Evaluirali smo istorije bolesti pacijenata sa NHL, HL i HLL dijagnostifikovanih u skladu sa klasifikacijom SZO i lečenih u našoj ustanovi između januara 2006. i decembra 2014. godine.

Rezultati: Od ukupno 1054 pacijenta, 48,4\% imalo je NHL visokog gradusa, 20,0\% NHL niskog gradusa, $14,5 \% \mathrm{HL}, 7,1 \%$ imalo je druge forme limfoma i $10,0 \%$ HLL. U grupi pacijenata sa limfomima, $72(6,8 \%)$ imalo je najmanje jednu TE. TE je uključivala trombozu dubokih vena (38,9\%), trombozu jugularnih vena (12,5\%), plućnu emboliju (11,1\%), trombozu CNS (6,9\%), trombozu površinskih vena $(2,8 \%)$, akutni infarkt miokarda $(1,4 \%)$ i ostalo $(26,4 \%)$. Kod 49 pacijenata tromboza se pojavila u toku terapije ili do tri meseca nakon završetka terapije, dok je kod 23 pacijenta tromboza dijagnostifikovana pre terapije. Pacijenti sa agresivnim formama NHL i HLL imali su značajno veću incidencu TE $(8,63 \%$, $8,57 \%$ ) u poređenju sa pacijentima sa drugim tipovima limfoma $(p=0,009)$. Nije postojao statistički značajno povećan rizik od TE u zavisnosti od tipa limfoproliferativne bolesti.

Zaključak: Ova studija je potvrdila rezultate ranijih studija o povećanom riziku od tromboembolijskih događaja (TE) kod pacijenata sa agresivnim oblicima hroničnih limfoproliferatvnih bolest, ali i da ne postoji statistički značajna razlika u odnosu na pol i godine.

Ključne reči: tromboembolijski događaj, nonHodžkin limfom, Hodžkin limfom, hronična limfocitna leukemija

\section{Abstract}

Introduction: An increased risk for thromboembolism in cancer patients has been observed in patients with solid tumours, whereas little data exist on malignant lymphoma.

Aim: Determination of the incidence of TE in patients with non Hodgkin lymphoma (NHL), Hodgkin lymphoma (HL) and chronic lymphocytic leukemia (CLL) treated in our institution.

Material and methods: We reviewed medical records of patients with NHL, HL and CLL diagnosed according to the WHO classification and treated at our institution between january 2006. and december 2014.

Results: A total of 1054 patients, $48.4 \%$ had highgrade NHL, 20.0\% low-grade NHL, $14.5 \% \mathrm{HL}, 7.1 \%$ other forms of lymphoma and $10.0 \%$ CLL. In group of lymphoma patients, $72(6.8 \%)$ had at least one TE. TE included deep vein thrombosis (38.9\%), jugular vein thrombosis (12.5\%), pulmonary embolism (11.1\%), CNS thrombosis $(6.9 \%)$, superficial vein thrombosis $(2.8 \%)$, acute myocardial infarction (1.4\%) and other (26.4\%). In 49 patients thrombosis occurred during treatment or up to three months after therapy completion, whereas in 23 patients thrombosis was diagnosed prior to therapy. Patients with aggressive NHL and CLL had significantly higher incidence of TE $(8.63 \%, 8.57 \%)$ compared to other types of lymphoma patients $(\mathrm{p}=0.009)$. There is no statistical significance of impact of different types of lymphoproliferative diseases on increased risk for TE.

Conclusion: This study confirmed findings of some earlier studies of increased risk of thromboembolic events (TE) in patients with agressive forms of chronic lymphoproliferative diseasses, but there is no significantly impact of gender or age on that risk.

Keywords: thromboembolic event, non-Hodgkin lymphoma, Hodgkin lymphoma, chronic lymphocytic leukaemia. 


\section{Introduction}

A thromboembolic event (TE) occurs in approximately $15 \%$ of patients with malignant disease [1] and patients with malignancies who develop thromboembolism usually have shorter overall survival time [2]. Additionally, cancer is frequently found in patients hospitalized for idiopathic TE or develops subsequently $[3,4]$. Malignancies of the lung, brain, liver and kidney carry a particularly high risk for TE developing [3], additional risk factors being extensive malignant disease as well as chemotherapy or hormonal therapy [5-7]. Cancer patients with TE have a higher mortality and recurrence rate than patients with idiopathic TE [8]. A couple of studies analyzed the incidence of thromboembolism in patients with haematologic malignancies. Earlier studies showed an increased incidence of thrombosis in patients with high grade non-Hodgkin lymphoma (hgNHL), Hodgkin lymphoma (HL) and CNS lymphoma [9-12]. Some studies also showed an increased risk of NHL and HL in patients within a year after a venous thromboembolism [3,4]. However, in those studies, patient numbers were either small or there was not enough pieces of information on the lymphoma types, and analysis rather looked at increased cancer risk in a thrombosis patient than at thrombosis risk in lymphoma patients.

The aim of this study is to determine incidence of thromboembolic events in patients with non Hodgkin lymphoma, Hodgkin lymphoma and chronic lymphocytic leukaemia who were treated in our institution.

\section{Matherial and methods}

We reviewed all medical records of patients with malignant lymphoproliferative diseases treated at Clinic of Hematology Clinical center of Serbia. We included patients with diagnosed NHL, HL i CLL between January 2006. and December 2014. according to the current WHO classification [13]. Patients with multiple myeloma, benign lymphadenopathy or acute forms of leukaemia were excluded from analysis in this study. Thromboembolic events had been confirmed by venography or ultrasound (for deep venous thrombosis (DVT), upper extremity thrombosis, central venous catheter thrombosis and portal vein thrombosis), computed tomography or scintigraphy (for pulmonary embolism (PE)), magnetic resonance imaging (for central nervous system (CNS) thrombosis) or angiogram (for arterial thrombosis). In all patients with medical records reviewed in this study, including patients with detected TE, we reviewed presence of additional risk factors for TE, showed in earlier studies, as malignancy localization in patients with solid forms of lymphoproliferative diseases, platelet and leukocyte number, level of hemoglobin, body mass index (BMI), reduced mobility of patient, presence of thrombophyllic conditions, presence of recent trauma or surgical procedure, heart or respiratory failure, hormonal therapy, presence of neutropenia, placed central venous catheter and clinical stage of disease [12, 14-21].

Patients were catagorised into five clinical groups: hgNHL, lgNHL [22], HL, CLL and group of remaining lymphoproliferative diseases ( $\mathrm{T}$ cell NHL, prolymphocytc leukaemia (PLL), hairy cell leukaemia (HCL), mantle cell lymphoma and mycosis fungoides (MF)) [13, 22-24]. Clinical stages were determined accoding to current classifications [25-17]. TE were cathegorized in seven groups: DVT, PE, internal jugular vein thrombosis, acute miocardial infarction (AIM) and group of remaining localizations of thrombosis. Data were collected in a Microsoft Office Excel 2013 database, and analyzed in IBM SPSS statistics v. 22 software package. Correlation of the TE incidence with subtype of disease, gender and age were calculated using Fisher's exact test.

\section{Results}

A total of 1054 patients, with malignant lymphoproliferative diseases were included in analysis for this study, 576 patients were men (54.6\%) and 478 were women $(45.4 \%)$. Mean age was $59.2 \pm 15.2$ years. A total of $510(48.4 \%)$ patients had hgNHL, $211(20.0 \%)$ had lgNHL, 153 (14.5\%) had HL and 75 (7.1\%) had other types of lymphoma. Diagnosed CLL had 105 (10.0\%) patients. Out of 1054 patients included in this study, $72(6.8 \%)$ had at least one TE. Forty patients were men and 32 women. In 72 patients with TE, $38.9 \%$ had DVT, $11.1 \%$ PE, $12.5 \%$ internal jugular vein thrombosis, $6.9 \%$ CNS thrombosis, $2.8 \%$ superficial vein thrombosis, $1.4 \%$ AIM and $26.4 \%$ other thrombosis localizations. In $49(68 \%)$ of patients TE occured during treatment or in the period of the first three months after completion of treatment, whereas in 23 (32\%) of patients TE was diagnosed prior to therapy initiation.

Table 1. Incidence of thromboembolic events in patients with chronic malignant lymphoproliferative diseases according to disease groups

\begin{tabular}{|l|c|c|c|}
\hline \multicolumn{1}{|c|}{ Diagnosis } & $\begin{array}{c}\text { Number of } \\
\text { patients }\end{array}$ & $\begin{array}{c}\text { Number of pa- } \\
\text { tients with TE }\end{array}$ & $\begin{array}{c}\text { Incidence of } \\
\text { TE (\%) }\end{array}$ \\
\hline hgNHL & 510 & 44 & 8.63 \\
\hline lgNHL & 211 & 9 & 4.26 \\
\hline HL & 153 & 5 & 3.27 \\
\hline CLL & 105 & 9 & 8.57 \\
\hline Other types & 75 & 5 & 6.67 \\
\hline Total & 1054 & 72 & 6.83 \\
\hline
\end{tabular}


icant higher rate of TE $(8.63 \%, 8.57 \%)$ compared to patients with other types of malignant lymph oproliferative diseases $(\mathrm{RR}=2.1 ; 95 \% \mathrm{CI}$ for $\mathrm{RR} 1.2-3.6 ; \mathrm{p}=0.009)$. In group of patients with lgNHL rate of TE had value of $4.26 \%$, with HL $3.27 \%$, and with other types of lymphoproliferative diseases $6.67 \%$ (Table 1).

Group analysis of patients with high grade lymphoma showed a slightly higher TE rate in male patients $(9.5 \%$ vs $7.7 \%)$ without statistical significance $(\mathrm{p}=0.275)$. In this group of patients mean age was 55.53 years (1887 years), $44.3 \%$ of patients was 60 years of age or more and statistically significant difference of TE rate was verified in subgroups of patients with 60 years of age or old$\mathrm{er}$, and younger than 60 years, with significantlly higher incidence of TE in patients younger than 60 years of age ( $15.4 \%$ vs $5.1 \% ; p=0.011)$. In patients with lgNHL, mean age value was 55.11 years with age span $18-76$ years.

Patients with 60 years of age or older contributed with $30.7 \%$. This group of patients also did not show significant difference between TE rate in patients correlated to age $(\mathrm{p}=0.522)$ and gender $(\mathrm{p}=0.097)$.

Group of patients with HL had mean age 34.54 years (15-60 years). In this group, there was $5.4 \%$ patients with 60 years of age or older and no one had TE. Statistically significant difference in TE rate in this group was not found according to gender of patients $(\mathrm{p}=0.232)$.

TE rate in group of patients with CLL was $8.6 \%$. Age span was 29-84 years with mean age value of 59.12 years. Statistical significance of TE incidence in patients older or younger than 60 years was not detected $(\mathrm{p}=0.311)$, although patients with 60 years of age or older contributed with $58.9 \%$ in this patient group. Also, significance was not found observing gender of patients $(\mathrm{p}=0.095)$.

Out of 1054 patients with chronic malignant lymphoproliferative diseases, $1.7 \%$ (18 patients) had CNS lymphoma. In that group of patients, TE was verified in $11.1 \%$ of cases, in contrast to $6.8 \%$ which is rate of TE in patients without CNS involvement. However, statistical significance was not detected $(p=0.351)$. All these findings failed to reach statistical significance due to the overall low number of thromboembolic events in patient cohort group (Table 2 and 3 ).

Table 2. Incidence of thromboembolic events in patients with chronic malignant lymphoproliferative diseases correlation with gender

\begin{tabular}{|c|c|c|c|}
\hline Diagnosis & Male (\%) & Female (\%) & $\mathrm{p}$ value \\
\hline hgNHL & 9.5 & 7.7 & 0.275 \\
\hline lgNHL & 1.9 & 6.5 & 0.097 \\
\hline HL & 4.9 & 1.4 & 0.232 \\
\hline CLL & 5.5 & 15.6 & 0.095 \\
\hline Total & 6.94 & 6.69 & 0.486 \\
\hline
\end{tabular}

Table 3. Incidence of thromboembolic events in patients with chronic malignant lymphoproliferative diseases correlation with age

\begin{tabular}{|c|c|c|c|}
\hline Diagnosis & $\begin{array}{c}\geq 60 \text { years of } \\
\text { age }(\%)\end{array}$ & $\begin{array}{c}<60 \text { years of } \\
\text { age }(\%)\end{array}$ & p value \\
\hline hgNHL & 5.1 & 15.4 & 0.011 \\
\hline lgNHL & 1.9 & 6.5 & 0.522 \\
\hline HL & 0.0 & 5.4 & 0.899 \\
\hline CLL & 9.3 & 3.3 & 0.311 \\
\hline Total & 6.94 & 6.69 & 0.486 \\
\hline
\end{tabular}

\section{Discussion}

Our analysis shows an increased incidence of TE of approximately $7 \%$ in patients with chronic malignant lymphoproliferative diseases. The highest incidence was observed among patients with hgNHL and CLL, whereas a much lower incidence was seen in patients with lgNHL and HL.

Mohren et al. showed correlation between increased incidence of TE in cases with bad outcome of diseases [12]. Our results are consistent with this finding, showing slightly lower incidence of TE in patients with hgNHL. Earlier studies also did not show significant difference between TE rate in patients with 60 years of age and older and patients younger than 60 years of age. In our study we showed significantly higher incidence of TE in patients with hgNHL younger than 60 years of age, which is in contrast to the most of earlier studies. Similar to one of the earlier researches which showed higher incidence in patients with CNS lymphoma [11], we also showed the same result, although without statistical significance. Analysis of data of TE incidence in research of Mohren et al. [12] has not been made in group of patients with lgNHL because of patients with CLL was included in this group. For this reason, and for reason of different classifications of clinical stages $[25,28,29]$, we separate these two groups of patients. Although, we still did not get statistical significance of increased incidence of TE between patients of different age or gender subgroups in these two groups of lymphoproliferative diseases.

The largest number of detected TE in patients included in this study occured during the use of chemoterapy protocol or in the first three months period after completing the treatment.

Data about congenital or acquired thrombophyllic conditions, as presence of anticardiolipin antibodies or antithrombin, deficiency of protein $\mathrm{C}$ or protein $\mathrm{S}$, presence of mutation of gene which codes prothrombin or Leiden mutation of factor $\mathrm{V}$ was not found among patients in this cohort group. 


\section{Conclusion}

Our study confirms findings in some of earlier studies of increased risk for TE in patients with agressive forms of lymphoma and CLL, but there is no statistical significance which would indicate the influence of gender or age on increased risk for TE occurrence, except in case of high grade NHL where patients younger than 60 years of age have higher risk for TE with regard to patients with 60 years of age or older.

\section{References}

1. Deitcher R. Cancer and thrombosis: mechanism and treatment. J Thrombosis Thrombolysis. 2003;16(1/2):21-31.

2. Sorensen H, Mellemkjaer L, Olsen J, Baron J. Prognosis of cancers associated with venous thromboembolism. N Engl J Med 2000;343:1846-1850.

3. Baron J, Gridley G, Weiderpass E, Nyren O, Linet M. Venous thromboembolism and cancer. The Lancet 1998;351:1077-1080.

4. Murchison J, Wylie L, Stockton D. Excess risk of cancer in patients with primary venous thromboembolism: a national, population-based cohort study. $\mathrm{Br} \mathrm{J}$ cancer 2004;91:92-95.

5. Prandoni $\mathrm{P}$, Lensing A, Büller H, Cogo A, Prins $\mathrm{M}$, Cattelan A, et al. Deep-vein thrombosis and the incidence of subsequent symptomatic cancer. N Engl J Med 1992;327:1128-1133.

6. Sorensen H, Mellemkjaer L, Flemming H, Olsen J, Nielson G. The risk of a cancer after primary deep venous thrombosis or pulmonary embolism. N Engl J Med 1998;338:1169-1173.

7. Lee A, Levine M. Venous thromboembolism and cancer: risks and outcome. Circulation 2003;107:I17-I21.

8. Cushman M, Tsai A, White R, Heckbert S, Rosamond W, Enright $P$, et al. Deep vein thrombosis and pulmonary embolism in two cohorts: the longitudinal investigation of thromboembolism etiology. Am J Med 2004;117/1:19-25.

9. Ottinger H, Belka C, Kozole G, Engelhard M, Meusers P, Paar D, et al. Deep venous thrombosis and pulmonary artery embolism in high grade non Hodgkin's lymphoma: incidence, causes and prognostic relevance. Eur J Haematol 1995;54(3):186-194.

10. Seifter E, Young R, Longo D. Deep venous thrombosis during therapy for Hodgkin's disease. Cancer Treat Rep 1985;69(9):1011-1013.

11. Goldschmidt N, Linetsky E, Shalom E, Varon D, Siegal T. High incidence of thromboembolism in patients with central nervous system lymphoma Cancer 2003;98(6):12391242.

12. Mohren M, Markmann I, Jentsch-Ullrich K, Koenigsmann M, Lutze G, Franke A. Increased risk of thromboembolism in patients with malignant lymphoma: a single-centre analysis. Br J Cancer. 2005;92(8):1349-51.
13. Swerdlow SH, Campo E, Harris NL, Pileri S, Stein H, Jaffe ES. WHO Classification of Tumours of Haematopoietic and Lymphoid Tissues. Lyon, France: IARC Press 2008.

14. Khorana AA, Kuderer NM, Culakova E, Lyman GH, Francis CW. Development and validation of a predictive model for chemotherapy-associated thrombosis Blood 2008;111:4902-7.

15. Barbar S, Noventa F, Rosetto V, Ferrari A, Brandolin B, Perlati M, et al. A risk assessment model for the identification of hospitalized medical patients at risk for venous thromboembolism:the Padua Prediction Score. J Thromb Haemost. 2010;8(11):2450-2457.

16. Khorana AA, Francis CW, Culakova E, Fisher RI, Kuderer NM, Lyman GH. Thromboembolism in hospitalized neutropenic cancer patients. J Clin Oncol. 2006;24(3):484-90.

17. Kahn SR, Lim W, Dunn AS, Cushman M, Dentali F, Akl EA, et al. Prevention of VTE in nonsurgical patients: Antithrombotic Therapy and Prevention of Thrombosis, 9th ed: American College of Chest Physicians evidence-based clinical practice guidelines. Chest. 2012;141(suppl 2):195S-226S.

18. Geerts WH, Bergqvist D, Pineo GF, Heit JA, Samama $\mathrm{CM}$, Lassen MR, et al. Prevention of venous thromboembolism: American College of Chest Physicians evidence-based clinical practice guidelines (8th edition). Chest. 2008;133(suppl 6):381S-453S.

19. Geerts WH, Pineo GF, Heit JA, Bergqvist D, Lassen MR, Colwell CW, et al. Prevention of venous thromboembolism: the seventh ACCP Conference on Antithrom-botic and Thrombolytic Therapy. Chest. 2004;126(suppl 3):338S-400S.

20. Heit JA, O'Fallon M, Petterson TM, Lohse CM, Silverstein $\mathrm{MD}$, Mohr DN, et al. Relative impact of risk factors for deep vein thrombosis and pulmonary embolism: a population-based study. Arch Intern Med. 2002;162(11):12451248.

21. Khorana AA, Connolly GC. Assessing risk of venous thromboembolism in the patient with cancer. J Clin Oncol. 2009;27(29):4839-4847.

22. Stansfeld AG, Diebold J, Noel H, Kapanci Y, Rilke F, Kelényi G, et al. Updated Kiel classification for lymphomas Lancet 1988;1:292-93.

23. Jaffe ES. The 2008 WHO classification of lymphomas: implications for clinical practice and translational research. Hematology Am Soc Hematol Educ Program. 2009;52331. doi: 10.1182/asheducation-2009.1.523.

24. Campo E, Swerdlow SH, Harris NL, Pileri S, Stein H, Jaffe ES. The 2008 WHO classification of lymphoid neoplasms and beyond: evolving concepts and practical applications Blood 2011;117(19):5019-5032.

25. Loehr WJ, Mujahed Z, Zahn FD, Gray GF, Thorbjarnarson B. Primary lymphoma of the gastrointestinal tract: A review of 100 cases, Ann Surg 1969;170:232-238.

26. Carbone PP, Kaplan HS, Musshoff K, Smithers DW, Tubiana M. Report of the Committee on Hodgkin's Disease Staging Classification. Cancer Res. 1971;31(11):1860-1. 
27. Lister TA, Crowther D, Sutcliffe SB, Glatstein E, Canellos GP, Young RC, et al. Report of a committee convened to discuss the evaluation and staging of patients with Hodgkin's disease: Cotswolds meeting. J Clin Oncol. 1989;7(11):1630-6.

28. Rai KR, Sawitsky A, Cronkite EP, Chanana AD, Levy RN,
Pasternack BS. Clinical staging of chronic lymphocytic leukaemia Blood 1975;46(2):219-34.

29. Binet JL, Auguier A, Dighiero G, Chastang C, Piquet H, Goasquen J, et al. A new prognostic classification of chronic lymphocytic leukaemia derived from a multivariate survival analysis. Cancer 1981;48(1):198-206. 